\title{
Methods and Approaches of Extension in Artificial Insemination (AI) Innovation Adoption to Buffalo Livestock Business in Padang Pariaman District, West Sumatra
}

\author{
Ediset ${ }^{*}$ and Jaswandi
}

Faculty of Animal Science, Andalas University, Padang, West Sumatra, Indonesia

DOI: $\underline{10.36347 / \text { sjavs.2020.v07i09.002 }}$

| Received: 13.09.2020 | Accepted: 21.09.2020 | Published: 30.09 .2020

*Corresponding author: Ediset

Abstract

Original Research Article

This research was conducted in Padang Pariaman District, West Sumatra province. The purpose of this research was to know: a) outreach approach in the adoption of artificial insemination (AI) innovations applied to the business of Buffalo Farms in Padang Pariaman, and B) extension methods in the adoption of artificial insemination (AI) Innovations that applied to the business of Buffalo Farms in Padang Pariaman district. The research used a survey method approach and a secondary data analysis approach. Quantitative descriptive data analysis calculated using Likert scales. The results showed that the extension approach that has been implemented well by the extension agents in Padang Pariaman in the adoption of artificial insemination (AI)innovation on the business of Buffalo farming was into persuasive approach extension (persuasion/ Invitations), while on a pervasion approach extension (persuasion/invitation repetition) and compulsion approach extension (indirect compulsion) application was still a medium category, and in the coercion approach extension (Direct compulsion) application was still less category. The extension method carried out by the extension in the adoption of artificial insemination (AI) innovations in the business of Buffalo Farms in Padang Pariaman has not run optimally, where for the individual extension methods were in good category, while Group extension methods and the mass extension methods were in medium category.

Keywords: Innovation Adoption, Artificial Insemination, Extension Methods, Extension Approach.

Copyright @ 2020: This is an open-access article distributed under the terms of the Creative Commons Attribution license which permits unrestricted use, distribution, and reproduction in any medium for non-commercial use (NonCommercial, or CC-BY-NC) provided the original author and source are credited.

\section{INTRODUCTION}

The increase of Buffalo cattle population in West Sumatra from year to year has slowed down, and it can be seen from the population of Buffalo cattle in 2013 as many as 114,013 buffaloes and in 2014 as many as 118,844 buffaloes [1] Padang Pariaman is the district of West Sumatra province that most people run the business of Buffalo farming, but even though the business of this buffalo-run farm is still a side business with 1-5 buffaloes ownership scale. The maintenance system is done in a semi-intensive, where during the day Buffalo cattle are grazed then by night Buffalo cattle are attached near the farmer's house without using a cage.

The problem of Buffalo farms in this area is quite varied among others: the traditional maintenance pattern, reduced grazing land so that buffalo cattle are difficult to marry naturally, high stud slaughter that impact shortage of stud, slaughter productive breeding of females, lack of feed in a certain season, hard to detect in the silent heat, a high enough calf death (about
$10 \%)$, length of birth intervals and as well as negative impression on the Buffalo.

The business condition of the farm as above will because the population number of buffalo slowly increases while the other side of the meat needs increase with evidence of increasing the number of slaughtering buffalo cattle annually. The anticipation of the condition is by applying the relevant policies and programs so that the balance between availability of buffalo meat with demand for buffalo meat can be maintained, where one of government program that has been applied in Padang Pariaman District to support the development of the Buffalo Farm business is an extension program [2]. Said that extension aims to change the behavior of breeders, whether it is for technical business, the purpose of business and welfare of its own businesses. The extension process should take into consideration the dimensions of the extension element itself, especially material/message/innovation that will be delivered to the Buffalo breeders as the target of extension activities, so that innovations are convey in the extension is relevant to the problem 
confronted by the breeder and can answer the problems that exist in the breeder.

The type of innovations that have been delivered through the extension activities in Padang Pariaman District are innovations of artificial insemination (AI), type of AI innovations have been applied to Buffalo cattle since 2012 in this area. Preliminary survey conducted shows that there are several sub-districts in Padang Pariaman district that have applied artificial insemination (AI) in Buffalo cattle such as V Koto Kampung Dalam Sub District, VII Koto Sungai Sarik Sub District, 2x 11 Kayu Tanam Sub District, Batang Gasan Sub-district, and Ulakan Tapakis Sub-district, where the number of Buffalo breeder already implementing the innovations is \pm 100 breeders.

The purpose of extension activities will be achieved if in the implementation refers to the approach and method of relevant extension to the target conditions of the extension, for that so that the innovation of AI can be adopted by the Buffalo breeder should be aware of some Approach and extension methods that need to be applied by the extension at the time of submission of material related to the AI's innovations.

Extension approaches and extension methods that are usually used by extension in innovation adoption process include persuasive approach (invitation), pervasion approach (repetition), compulsion approach (Indirect compulsion) and coercion approach (direct compulsion), while the extension method applied by extension agents to implement innovation is individual extension method, group extension method and mass extension method.

\section{Based on the explanation above, the research problem is formulated as follows}

1. How the extension approaches in the adoption of artificial insemination (AI) innovation applied to the business of Buffalo farm in Padang Pariaman district.

2. How the extension method in the adoption of artificial insemination (AI) innovation applied to the business of Buffalo Farms in Padang Pariaman district.

\section{Based on the problems that have been formulated,} the research aimed to

1. Know the extension approach in the adoption of artificial insemination (AI) innovation applied to the business of Buffalo Farms in Padang Pariaman district.

2. Know the extension method in the adoption of artificial insemination (AI) innovation applied to the business of Buffalo Farms in Padang Pariaman district.
The results of this study are expected to be beneficial as information or scientific reference for all stakeholders as:

1. Guidance for the extension agents to apply the appropriate strategy in implementing the extension in the future, both for the same type of innovation as well as different types of innovations, whether it is for Padang Pariaman Regency and other areas.

2. Evaluation material for government in measuring the success rate of extension program.

3. Reference for academics, both for research and for additional information in formulating the theory of extension strategies relevant to the social culture conditions of the target.

\section{MATERIALS AND METHOD \\ Research location}

This study was conducted in 5 sub-districts in Padang Pariaman regency of West Sumatera province, namely in V Koto Kampung Dalam Sub District, VII Koto Sungai Sarik Sub District, 2 x11 Kayu Tanam Sub District, Batang Gasan sub District and Ulakan Tapakis Sub-district. 5 (five) of these sub-districts are the places where artificial insemination (AI) innovation has been implemented.

\section{Data Collection}

The data collected on this research were primary data and secondary data according to research needs. The primary Data were derived from the results of a live interview with the breeders in the research location and with a thorough interview (In depth Interview) related stakeholders who are considered to be aware of the issues studied. Primary Data was used to identify the characteristics of buffalo farms, approaches and extension methods in the adoption of artificial insemination (AI) innovations. Meanwhile, secondary data was obtained from the literature, BPS, livestock office, District Extension Agency and other relevant agencies.

\section{Population and Research Samples}

The population of this research was a buffalo breeder who has adopted an artificial insemination (AI) innovation. Determination of the number of samples was conducted with the formula Slovin so that the sample obtained as many as 50 breeders, while the determination of samples using accidental sampling was a sampling technique based on coincidence, which anyone who coincidentally /accidental meet with researchers can be used as a sample [3].

\section{Data Processing and Analysis Methods}

Research objectives, 1) extension methods, 2) extension approaches, in a quantitative descriptive analysis, which was calculated using a Likert scale. Likert scales are used to measure one's attitude, opinion, and perception of a group about social phenomena [4]. 
Through the Likert scale, variables will be measured and spelled out via variable indicators. Then the indicator is used as a starting point for arranging instrument items that can be a statement or a question [4].

For quantitative analysis, answers were given the following scores

1. Agree (ST): Score 3

2. Hesitant (RR): Score 2

3. Disagree (TS): Score 1
4. Aspect Data obtained, collected in the form of tables, and then calculated based on the respective score-each according to the "Guidelines for Identification Technical Determinants Factors [5]. Furthermore, the score obtained will be compared with the category established [5] namely:

a) Good category, percentage earned $81-100 \%$

b) Medium category, percentage earned $60-80 \%$

c) Less Category, percentages earned less than $60 \%$.

\section{RESULTS AND DISCUSIONS}

Extension Approach in Adoption of Artificial Insemination (AI) Innovation in Buffalo Livestock Business

Table-1: Extension Approach Category in Adoption of AI Technology Innovation

\begin{tabular}{|c|c|c|c|c|c|c|}
\hline \multirow[t]{2}{*}{ No } & \multirow{2}{*}{ District } & \multicolumn{5}{|c|}{ Extension Approach } \\
\hline & & $\begin{array}{l}\text { Persuasive } \\
\text { \% Category } \\
\text { Score }\end{array}$ & $\begin{array}{l}\text { Pervasion } \\
\% \text { Category } \\
\text { Score }\end{array}$ & $\begin{array}{l}\text { Compulsion } \\
\text { \% Category } \\
\text { Score }\end{array}$ & $\begin{array}{c}\text { Coersion } \\
\% \text { Category } \\
\text { Score }\end{array}$ & $\begin{array}{l}\text { Average } \\
\% \text { Category } \\
\text { Score }\end{array}$ \\
\hline 1 & VII Koto Sungai Sarik & $\begin{array}{l}90,70 \\
\text { good }\end{array}$ & $\begin{array}{c}60,00 \\
\text { medium }\end{array}$ & $\begin{array}{l}85,71 \\
\text { good }\end{array}$ & $\begin{array}{c}50,00 \\
\text { less }\end{array}$ & $\begin{array}{c}71,60 \\
\text { medium }\end{array}$ \\
\hline 2 & V Koto Kampung Dalam & $\begin{array}{l}81,82 \\
\text { good }\end{array}$ & $\begin{array}{c}47,37 \\
\text { less }\end{array}$ & $\begin{array}{c}71,43 \\
\text { medium }\end{array}$ & $\begin{array}{c}63,16 \\
\text { medium }\end{array}$ & $\begin{array}{c}65,95 \\
\text { medium }\end{array}$ \\
\hline 3 & Ulakan Tapakis & $\begin{array}{l}91,07 \\
\text { good }\end{array}$ & $\begin{array}{c}73,47 \\
\text { medium }\end{array}$ & $\begin{array}{l}85,71 \\
\text { good }\end{array}$ & $\begin{array}{c}75,00 \\
\text { medium }\end{array}$ & $\begin{array}{l}81,31 \\
\text { good }\end{array}$ \\
\hline 4 & Batang Gasan & $\begin{array}{c}78,95 \\
\text { medium }\end{array}$ & $\begin{array}{c}77,14 \\
\text { medium }\end{array}$ & $\begin{array}{c}70,59 \\
\text { medium }\end{array}$ & $\begin{array}{c}68,57 \\
\text { medium }\end{array}$ & $\begin{array}{c}73,81 \\
\text { medium }\end{array}$ \\
\hline 5 & 2x 11 Kayu Tanam & $\begin{array}{c}83,33 \\
\text { good } \\
\end{array}$ & $\begin{array}{c}79,25 \\
\text { medium }\end{array}$ & $\begin{array}{c}85,71 \\
\text { good }\end{array}$ & $\begin{array}{c}65,22 \\
\text { medium }\end{array}$ & $\begin{array}{c}78,38 \\
\text { medium }\end{array}$ \\
\hline & Padang Pariaman District & $\begin{array}{l}85,17 \\
\text { good }\end{array}$ & $\begin{array}{c}67,45 \\
\text { medium }\end{array}$ & $\begin{array}{c}79,83 \\
\text { medium }\end{array}$ & $\begin{array}{c}64,39 \\
\text { medium }\end{array}$ & $\begin{array}{c}74,21 \\
\text { medium }\end{array}$ \\
\hline
\end{tabular}

Source: Research Results of 2017

\section{Persuasive Approach Extension (persuasion/solicitation)}

The results showed that in delivering the extension material about the innovation of artificial insemination $(\mathrm{AI})$, extension in Padang Pariaman district has implemented a good into extension approach, which as many as $85.17 \%$ of buffalo breeders said that in conducting extension activities, especially related to this AI innovation, the extension has already implemented the extension approach.

This persuasive approach extension was conducted by extension agents because the innovation of artificial insemination (AI) in the business of Buffalo cattle was a new innovation introduced in Padang Pariaman Regency. For the adoption of AI innovations can happen quickly, the extension agents should work seriously and actively come to the breeders to make invitations and persuasion so that the Buffalo breeders will adopt the innovation of the AI, besides it was necessary to also pay attention to the social economic status because of adoption of innovation decisions was usually influenced by the social-economic status [6]. Said that several factors influencing the speed of a person to adopt innovation are the scale of business, income, age, courage to take a risk, level of activity and membership status of the group.

\section{Pervasion Approach Extension (recurrence persuasion/invitation)}

This research showed the results that $67.45 \%$ of Buffalo Breeders said that the extension of providing information about artificial insemination (AI) innovations in Padang Pariaman District used a pervasion approach, meaning the percentage of the perception of the Buffalo breeders indicated that the extension of the pervasion approach was in medium category. The factors that led to the extension approach of this pervasion has not been carried out optimally in Padang Pariaman District was the result of the limited number of extension personnel in each of the sub district Agricultural Extension Agency (AEA) so that the Extension agents have limited time and energy to come to the breeders to do repeated invitations and persuasion and beside that target breeders also less initiative to come to the extension agents, which should breeders do in looking for information relating to innovation, especially the AI innovation itself, as well as breeders were also less utilizing other sources of information to add to their knowledge [2]. Stated that the difference between an innovative breeder and a less 
innovative breeder is that the innovative breeder usually utilizes a wide range of information sources related to innovation such as higher Education, Research institutions, related agencies, media, public figures and commercial institutions such as merchants.

\section{Compulsion Approach Extension (indirect compulsion)}

Breeders of research respondents agreed $79.83 \%$, if the extension in the research area has implemented a compulsion approach in conducting extension with materials related to the innovation of artificial insemination (AI), it means the use of this approaches by the extension agents in providing extension to the breeder was in medium category. The compulsion extension approach can basically be conducted by indirectly coercion to Buffalo breeders by creating a condition, so that with this condition the Buffalo breeders will adopt the AI innovations that offered. [7] present hypothesized that the speed of innovation adoption is influenced by the socioeconomic status of the recipient or the user of innovation, in which only $2.5 \%$ of society is included in the pioneering group (innovator). Where the socioeconomic status of the farmer is only a large amount of domestic breeders' household income.

\section{Coercion Approach Extension (direct compulsion) \\ Research showed that coercion approach} extension was in medium category with percentage of $64.39 \%$, it means not all buffalo breeders in Padang Pariaman District agreed that the coercion approach extension has been applied in delivery of Artificial insemination (AI) technology material. The extension approach of coercion was more directly pushy, either by awarding the award as well as punishment. The cause of the coercion approach has not been conducted was the low success rate of the AI program in Padang Pariaman district. The low AI success rate will cause an extension agents difficulty of forcing Buffalo breeders to adopt the AI innovations because however, Buffalo breeders or adopters will primarily be guided at the success rate of a program, despite the status Social economics such as business scale, income, risk, age, etc. sometimes can also affect decision making for the adoption of an innovation [8]. Said that in Dharmasraya district West Sumatra, Socio-economic status such as age, business scale, income, risk, activity and group status did not affect the cattle breeder in the adoption of AI innovations.

Extension Methods in Adoption of Artificial Insemination (AI) Innovations towards Buffalo Livestock Business

Table-2: Extension Approach Category in Adoption of AI Technology Innovation

\begin{tabular}{|c|l|c|c|c|c|}
\hline \multirow{2}{*}{ No } & \multirow{2}{*}{ District } & \multicolumn{4}{|c|}{ Extension Approach } \\
\cline { 3 - 6 } & & $\begin{array}{c}\text { Individual } \\
\text { \% Categori } \\
\text { Score }\end{array}$ & $\begin{array}{c}\text { Group } \\
\% \text { Categori } \\
\text { Score }\end{array}$ & $\begin{array}{c}\text { Mass } \\
\% \text { Categori } \\
\text { Score }\end{array}$ & $\begin{array}{c}\text { Average } \\
\% \text { Categori } \\
\text { Score }\end{array}$ \\
\hline 1 & VII Koto Sungai Sarik & $\begin{array}{c}87,80 \\
\text { good }\end{array}$ & $\begin{array}{c}78,95 \\
\text { medium }\end{array}$ & $\begin{array}{c}65,75 \\
\text { medium }\end{array}$ & $\begin{array}{c}77,50 \\
\text { medium }\end{array}$ \\
\hline 2 & V Koto Kampung Dalam & 73,17 & 69,23 & 61,54 & 67,98 \\
& & medium & medium & medium & medium \\
\hline 3 & Ulakan Tapakis & 91,07 & 88,89 & 70,59 & 83,52 \\
& & good & good & medium & good \\
\hline 4 & Batang Gasan & 83,33 & 78,95 & 56,25 & 72,84 \\
& & good & medium & medium & medium \\
\hline 5 & 2x 11 Kayu Tanam & 77,78 & 66,67 & 76,92 & 73,79 \\
& & medium & medium & medium & medium \\
\hline & Padang Pariaman District & 82,63 & 76,54 & 66,21 & 75,13 \\
& & good & medium & medium & medium \\
\hline
\end{tabular}

Source: Research Result of 2017

\section{Individual Extension Methods}

The results showed that $82.63 \%$ of buffalo breeders in Padang Pariaman District agreed that the extension methods used by the extension agents to convey innovation of artificial insemination (AI) was an individual method. The percentage of this score illustrates that the implementation of the individual extension methods was in good category. The implementation of the individual extension method was good because the artificial insemination (AI) program on Buffalo Cattle in new research areas was introduced, so related agency conducted home visits and livestock business in order the AI innovation Can immediately be known by buffalo breeders and as soon as possible in the adoption by breeders, because usually in the process of adoption of new innovations that become an obstacle in media delivery, if delivered through the mass media then the process of innovation adoption will be slow [9]. Says that the obstacles in the adoption of reproductive biotechnology innovations are media usage, especially the utilization of mass media as a source of innovation. 


\section{Group extension method}

Referring to the table above, the group extension method was in medium category, which based on the research results got that $76.54 \%$ of buffalo breeders in Padang Pariaman District agreed that the implementation of extension activities on innovation Artificial insemination (AI) was conducted by extension agents using group extension method, but the implementation was not optimal (medium category), this was because it was difficult to bring all buffalo breeders to an adopter of AI in each extension activities where buffalo breeders have different main jobs [2]. added that the time and place of implementation of the extension should be adjusted to the target conditions (physical environment, economic ability and social values). The condition of the breeder should be addressed with carefully by extension agents, because if neglected, the process of adoption of innovation will not occur, in addition extension agents should also take note of other factors that affect the adoption process [10]. States that adoption of technology is driven by factors such as, 1) socio-economic, 2) agroecology, 3) institutional, 4) information, 5) farmer perception, 6) behavior and 7) technological problems

\section{MASS EXTENSION METHODS}

The research showed that only $66.21 \%$ of buffalo breeders in Padang Pariaman agreed if the mass extension methods were applied by the extension agents in conducting artificial insemination innovation (AI) extension activities. The percentage proved that the mass extension method was only in the category of medium, where if referring to the Decree [5] There are several categories of implementation based on the percentage rate, including: good category (81-100\%), Medium category (60-80\%) And the less category (< $60 \%)$. The lack of application of mass extension methods caused by each breeder has a different profession as well as most breeders in conducting farms business is only a side business, so that with conditions like this then extension by using a mass extension method would be difficult to direct the activities on the breeder because of the extension agents conducting the extension activities, breeders struggling with their respective work so that the present only a small part only [11]. Stated that the mass/general approach is a meeting that is held to the general public with a large enough amounts to convey a particular intent, through this meeting is expected to be able to reach larger target groups.

\section{CONCLUSION}

1. The extension approach that had been well implemented by the extension agents in Padang Pariaman in the adoption of artificial insemination (AI) innovation on the business of buffalo farming was a persuasive extension approach (persuasion/solicitation), while the pervasion approach Extension (Recurrence of inducement/solicitation), compulsion approaches extension (indirect compulsion) and a coercion approach extension (direct compulsion) were still being applied in medium category.

2. The extension method that had been applied to the category either by extension in the adoption of artificial insemination (AI) innovation on the business of buffalo farms in Padang Pariaman was an individual extension method, while the group extension methods and the mass extension methods were in medium category.

\section{REFERENCE}

1. Dinas Peternakan dan Kesehatan Hewan. Pupulasi Ternak Besar Menurut Jenisnya dalam Angka. Dinas Peternakan dan Kesehatan Hewan, Sumatera Barat.2014.

2. Anwar S, Madarisa F, dan Anas A Ilmu Penyuluhan Pertanian, Universitas Andalas, Padang.2009.

3. Silalahi U. Metodologi Penelitian Sosial. PT Refika Aditama, Bandung.2009.

4. Sugiyono. Metode Penelitian Kuantitatif Kualitatif dan R\&D. Alfabeta. Bandung.2014.

5. Ditjen Peternakan. Pedoman Identifikasi Faktor Penentu Teknis Peternakan. Proyek Peningkatan Produksi Peternakan . Diklat Peternakan. Jakarta.1992.

6. Mardikanto. 2010. Komunikasi Pembangunan. Sebelas Maret university press. Surakarta. Rogers EM and Schoemaker FF. Communication of Innovations: A Cross Cultural Approach. Revised Edition. New York: The Free Press.1995.

7. Rogers and Everett M. Diffusion of Innovations (Fourth Edition). The Free Press. New York. 1995.

8. Ediset dan Jaswandi. Metode Penyuluhan Dalam Adopsi Inovasi Inseminasi Buatan (IB) pada Usaha Peternakan Sapi Di Kabupaten Dharmasraya. Jurnal Peternakan. UIN SUSKA Riau.2017; 14(1):1-10.

9. Ediset dan Jaswandi. Kendala Adopsi Inovasi Bioteknologi Reproduksi Pada Usaha Peternakan Sapi Di Daerah Transmigrasi Kabupaten Dharmasraya. Jurnal Peternakan Indonesia (JPI) Fakultas Peternakan. Universitas Andalas Padang. 2016; 18(2).

10. Tey YS and Brindal M. Factors Influencing the Adoption of Precision Agricultural Technologies: A Review for Policy Implication. Precision Agriculture. 2012; 13, 713-730.

11. Suhardiyono L. Penyuluhan: Petunjuk Bagi Penyuluh Pertanian. Anggota IKAPI. Erlangga. Jakarta. 1990. 